\title{
Pengaruh Perencanaan Pajak dan Kepemilikan Manajerial Terhadap Nilai Perusahaan dengan Transparansi Perusahaan Sebagai Variabel Moderasi
}

\author{
Sulistyo Wahyudin Hidayat ${ }^{*}$, David Adechandra Ashedica Pesudo ${ }^{2}$ \\ 1,2 Fakultas Ekonomika dan Bisnis Universitas Kristen Satya Wacana Salatiga
}

\author{
A R T I C L E I N F O \\ Article history: \\ Received 19 August 2019 \\ Received in revised form \\ 16 September 2019 \\ Accepted 15 October 2019 \\ Available online 30 \\ November 2019

\section{Kata Kunci:} \\ Perencanaan Pajak \\ Kepemilikan Manajerial, \\ Nilai Perusahaan, \\ Transparansi Perusahaan \\ Keywords: \\ Tax Planning, Managerial \\ Ownership, Corporate Value, \\ Corporate Transparency
}

\begin{abstract}
A B S T R A K
Penelitian ini bertujuan untuk mengetahui pengaruh perencanaan pajak dan kepemilikan manajerial terhadap nilai perusahaan dengan transparansi perusahaan sebagai variabel moderasi. Penelitian ini menggunakan laporan tahunan perusahaan manufaktur yang terdaftar di Bursa Efek Indonesia (BEI) tahun 20152017. Teknik analisis yang digunakan dalam penelitian ini yaitu deskriptif statistik, analisis regresi linear regresi linear berganda. Hasil pengujian ini menunjukkan perencanaan pajak berpengaruh positif terhadap nilai perusahaan, kepemilikan manajerial berpengaruh negative terhadap nilai perusahaan, dan transparansi perusahaan memoderasi hubungan antara perencanaan pajak dan kepemilikan manajerial terhadap nilai perusahaan. Hal ini di karenakan banyak informasi yang diungkapkan oleh manajemen pada laporan keuangan atau tahunannya, maka pemilik perusahaan dan investor dapat lebih mengetahui kondisi peusahaan yang sebenarnya.
\end{abstract}

\section{A B S T R A C T}

This study aims to determine the effect of tax planning and managerial ownership on firm value with company transparency as a moderating variable. This study uses annual reports of manufacturing companies listed on the Indonesia Stock Exchange (IDX) in 2015-2017. The analysis technique used in this study is descriptive statistics, multiple linear regression. The results of this test indicate tax planning has a positive effect on firm value, managerial ownership has a negative effect on firm value, and corporate transparency moderates the relationship between tax planning and managerial ownership of firm value. This is because there is a lot of information disclosed by management in its financial or annual reports, so that company owners and investors can better know the real condition of the company.

\footnotetext{
* Corresponding author.

E-mail addresses: sulistyowahyudin27@gmail.com (Sulistyo Wahyudin Hidayat)
} 


\section{Pendahuluan}

Perencanaan pajak adalah usaha yang dilakukan wajib pajak agar bisa meminimalkan kewajiban pajak yang akan dibayarkan. Hal ini dilakukan dengan cara menghindari pajak dan tidak melanggar tata tertib perpajakan (Suandy, 2011). Perencanaan pajak sangat efektif jika perusahaan dapat melakukan dan mempertimbangkan resiko dan manfaat yang diperoleh dari aktivitas tersebut. Perusahaan melaksanakan perencanaan pajak agar bisa menekan beban pajak yang harus dibayarkan (Hutami, 2011).

Perencanaan pajak dapat diterapkan apabila terdapat good governance (tata kelola yang baik) dari manajemen perusahaan. Corporate Governance ini akan menggambarkan hubungan seluruh pihak-pihak yang terkait agar jalannya kinerja perusahaan bisa ditentukan dengan baik. Menurut Nike et al (2014) selain itu dengan adanya corporate governance akan meningkatkan pengawasan seluruh kinerja perusahaan, sehingga dengan Corporate Governance diharapkan bisa menaikkan nilai perusahaan. Salah satu mekanisme corporate governance yang ada di dalam perusahaan adalah kepemilikan manajerial. Semakin banyak kepemilikan manager di dalam perusahaan maka agent akan cenderung untuk berupaya dalam meningkatkan kinerjanya.

Kegiatan perencanaan pajak merupakan satu dari sekian banyak cara yang dilakukan untuk memanipulasi pelaporan keuangan perusahaan. Salah satu berita terkait dengan hal ini adalah perusahaan Aramco yang dapat mengurangi pajak seperti, potong pajak, pemerintah Arab Saudi akan mengurangi tarif pajak 85 persen turun menjadi 50 persen. Dengan mengurangi tarif pajak secara drastis, semakin banyak uang yang akan keluar ke pemilik Saudi Aramco dibandingkan dengan pemerintah.

Berdasarkan tarif pajak baru, banyak dari pembayaran perusahaan kepada pemerintah diharapkan dalam bentuk dividen dan tidak dalam bentuk pajak. Jika menggunakan sistem pajak yang lama, sekitar 88 persen dari nilai pendapatan pergi ke pemerintah melalui royalti, setelah menggunakan sistem baru sekitar 60 persen dari keuntungan masuk ke pemerintah (industri.bisnis.com, 2017).

Nilai perusahaan pada umumnya tercermin dalam harga saham perusahaan itu sendiri. Nilai perusahaan dipengaruhi oleh faktor-faktor berikut ini yaitu, perencanaan pajak disebabkan karena dapat meminimalkan kewajiban pajak. Corporate governance bisa mempengaruhi kepemilikan manajerial. Selain kedua variable yang tertera transparansi perusahaan dapat memoderasi karena ada pengaruh antara perencanaan pajak dan nilai perusahaan. Dalam penelitian ini, penulis ingin mengembangkan penelitian dari peneliti sebelumnya Holland et al (2012) yaitu Corporate governance, Tax planning, dan nilai perusahaan. Perbedaan penelitian ini dari peneliti sebelumnya yaitu mengenai corporate governance dalam mempengaruhi hubungan perencanaan pajak terhadap nilai perusahaan. Penelitian menambahkan variabel transparansi perusahaan sebagai variable pemoderasi. Transparansi diduga dapat memperkuat atau memperlemah perencanaan pajak.

Penelitian yang dilakukan oleh Holland et al (2012) menemukan bahwa perencanaan pajak tidak berpengaruh signifikan terhadap nilai perusahaan, begitu juga di dalam penelitian Hairi et al (2016). Hasil yang berbeda diperoleh pada penelitian Lestari (2014) yaitu perencanaan pajak berpengaruh positif signifikan terhadap perencanaan pajak dan juga penelitian (Chasbiandani \& Martani, 2012).

Berdasar latar belakang yang diuraikan diatas maka bisa di rumuskan rumusan masalah yang diangkat yaitu: (1) Apakah perencanaan pajak dan kepemilikan manajerial berpengaruh terhadap nilai perusahaan? (2) Apakah transparansi perusahaan dapat memoderasi hubungan antara perencanaan pajak dan kepemilikan manajerial dengan nilai perusahaan?. Sehingga Penelitian ini bertujuan untuk menjelaskan pengaruh variable yang bisa mempengaruhi nilai perusahaan. Penelitian ini bermanfaat bagi: (1) Perusahaan, yaitu pemakai laporan keuangan dan manajemen perusahaan untuk memahami perencanaan pajak dan good corporate governance, (2) peneliti selanjutnya, yaitu sebagai bakal informasi dan dapat digunakan sebagai referensi untuk melakukan penelitian-penelitian selanjutnya.

\section{Metode}

Penelitian ini yaitu penelitian kuantitatif. Data yang diambil dalam penelitian ini yaitu laporan keuangan tahunan perusahaan-perusahaan manufaktur yang tercantum di Bursa Efek Indonesia (BEI) pada periode 2015 sampai 2017. Data-data tersebut diperoleh dari IDX data base (www.idx.co.id).

Populasi yang digunakan di dalam penelitian ini yaitu perusahaan sektor manufaktur yang tercantum dan menerbitkan laporan tahunannya dalam Bursa Efek Indonesia (BEI) periode 2015 sampai 2017. Perusahaan manufaktur dipilih karena perusahaan manufaktur merupakan perusahaan yang memiliki produksi yang berkesinambungan sehingga memerlukan pengelolaan modal yang baik dan menghasilkan profit yang besar dan bisa untuk mengembalikan investasi yang besar sehingga bisa menarik investor untuk menanamkan modalnya. Penelitian ini menggunakan metode purposive sampling yaitu pemilihan sampel secara tidak random yang informasinya diperoleh menggunakan pertimbangan 
tertentu umumnya disesuaikan dengan tujuan penelitian. Kriteria penentuan sampel yaitu (1) Perusahaan manufaktur yang tercatat di Bursa Efek Indonesia periode tahun 2015 - 2017 secara berturut-turut, (2) Perusahaan manufaktur yang mempublikasikan laporan tahunan dan laporan keuangan tahun 2015 2017 secara berturut - turut, (3) Perusahaan manufaktur tidak mengalami kerugian selama periode penelitian periode tahun 2015 - 2017, (4) Perusahaan manufaktur yang mempublikasikan laporan tahunan dan laporan keuangan periode tahun 2015 - 2017 dengan mata uang rupiah.

Tabel 1. Definisi Operasional dan Pengukuran Variabel Penelitian

\begin{tabular}{lll}
\hline $\begin{array}{l}\text { Jenis } \\
\text { Variabel }\end{array}$ & Variabel & Definisi Operasional \\
\hline $\begin{array}{l}\text { Variabel } \\
\text { Terikat }\end{array}$ & Nilai & $\begin{array}{l}\text { (Torihoran, 2016) } \\
\text { mengemukakan bahwa } \\
\text { nilai perusahan yaitu cara } \\
\text { pandang pemegang saham } \\
\text { yang dikaitkan dengan } \\
\text { harga saham. }\end{array}$ \\
& & \\
& & \\
& & \\
\hline Variabel & Perencanaan & \\
Bebas & Pajak & $\begin{array}{l}\text { Perencanaan pajak adalah } \\
\text { usaha yang dilakukan } \\
\text { perusahaan agar beban } \\
\text { pembayaran perusahaan } \\
\text { tidak terlalu tinggi. }\end{array}$ \\
& &
\end{tabular}

Pengukuran Variabel

Nilai perusahaan dihitung menggunakan rasio $Q$ atau Tobin's $Q$. Rasio Tobin's $Q$ memakai rumus sebagai berikut:

Tobins' $Q=\frac{(E M V+D)}{(E B V+D)}$

Keterangan :

Tobins $Q=$ Nilai Perusahaan

Equity Market Value $\quad=$ Nilai Pasar

Ekuitas

Equity Book Value = Nilai Buku dari

Total Ekuitas

(Debt) = Nilai Buku dari

Total Hutang

Variabel ini diukur menggunakan Effective

Tax Rate atau ETR seperti dalam penelitian

(Pradyana, 2017). ETR bisa dihitung menggunakan rumus:

$$
\text { ETR }=\frac{\text { Total Tax Expenses }}{\text { Pre Tax Income }}
$$

Keterangan :

ETR = Effective Tax Rate (Tarif Pajak Efektif)

Total Tax Expense $=$ Beban pajak

Pre Tax Income = Laba sebelum pajak

Kepemilikan Kepemilikan manajerial Kepemilikan manajerial diukur berdasar

Manajerial ialah proporsi pemegang

bagian saham yang dipunyai manajerial

saham dari pihak

manajemen dan aktif serta

ikut dalam pemungutan

keputusan perusahan

(Diyah P \& W.Erman,

2009).

perusahaan dari jumlah saham perusahaan

yang beredar JWahab dan Holland, 2012)

dalam (Winanto, 2013).

$K M=\frac{\text { saham yang dimiliki manajer }}{\text { saham beredar }}$

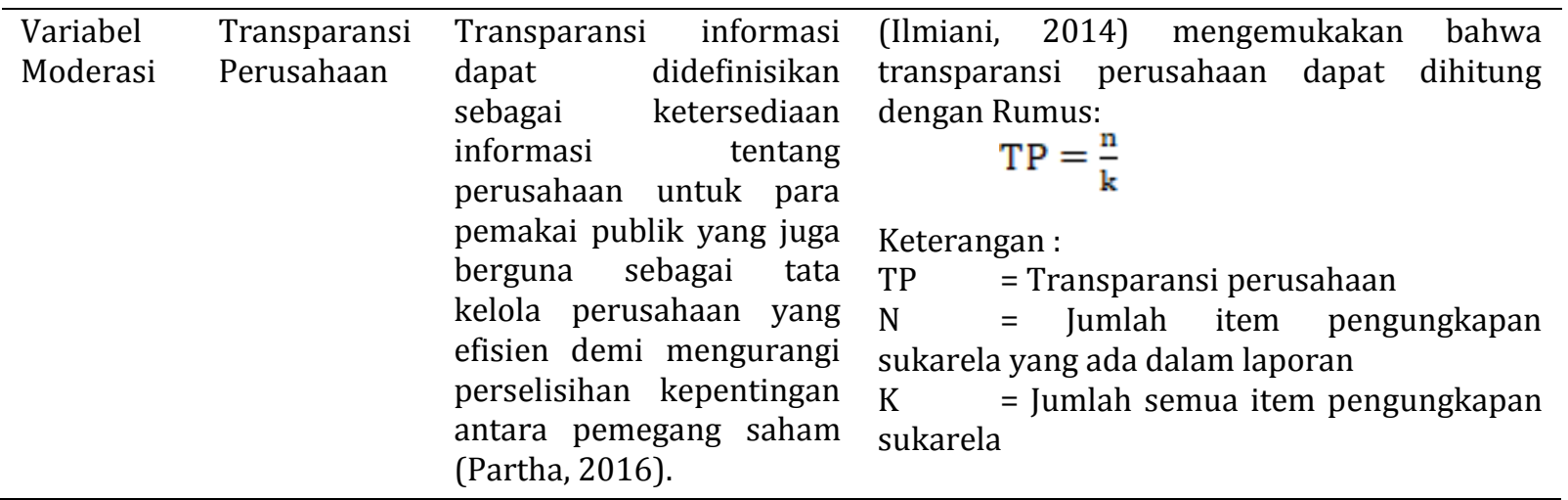


Luas pengungkapan sukarela menggunakan perhitungan indeks dari penelitian Nuryaman (2009) yang telah disesuaikan dengan Peraturan Otoritas Jasa Keuangan Nomor 29 /POJK.04/2016 Tentang Laporan Tahunan Emiten Atau Perusahaan Publik.

Metode analisis yang digunakan dalam penelitian ini yaitu model regresi linear berganda yang sebelumnya harus lolos uji asumsi klasik. Uji asumsi klasik yaitu ketentuan statistik yang harus dilengkapi pada analisis regresi linear berganda. Uji asumsi klasik yang digunakan melingkupi uji normalitas, autokorelasi, multikolinearitas, serta heteroskedastisitas.

Rumus regresi linear berganda adalah sebagai berikut :

1. Tobins' $\mathrm{Q}=\alpha+\beta 1 \mathrm{ETR}+\beta 2 \mathrm{KM}+\beta 3 \mathrm{TP}+\mathrm{e}$

2. Tobins' $\mathrm{Q}=\alpha+\beta 1 \mathrm{ETR}+\beta 2 \mathrm{KM}+\beta 3 \mathrm{TP}+\beta 4 \mathrm{ETR}^{*} \mathrm{TP}+\mathrm{e}$

3. Tobins' $\mathrm{Q}=\alpha+\beta 1 \mathrm{ETR}+\beta 2 \mathrm{KM}+\beta 3 \mathrm{TP}+\beta 5 \mathrm{KM}{ }^{*} \mathrm{TP}+\mathrm{e}$

Keterangan :

Tobins'Q

$\alpha$

: Nilai Perusahaan

$\beta \quad$ : Koefisien Regresi

ETR : Effective Tax Rate

KM : Kepemilikan Manajerial

TP : Transparansi Perusahaan

e : Error

\section{Hasil dan pembahasan}

Hasil Pengumpulan Data

Perusahaan manufaktur yang tercatat di Bursa Efek Indonesia pada tahun 2015-2017 merupakan populasi dari penelitian ini dan sampelnya dipilih dengan menggunakan metode purposive sampling, sehingga diperoleh sampel perusahaan sebanyak 58 perusahaan.

Tabel 2. Hasil Seleksi Sampel Perusahaan

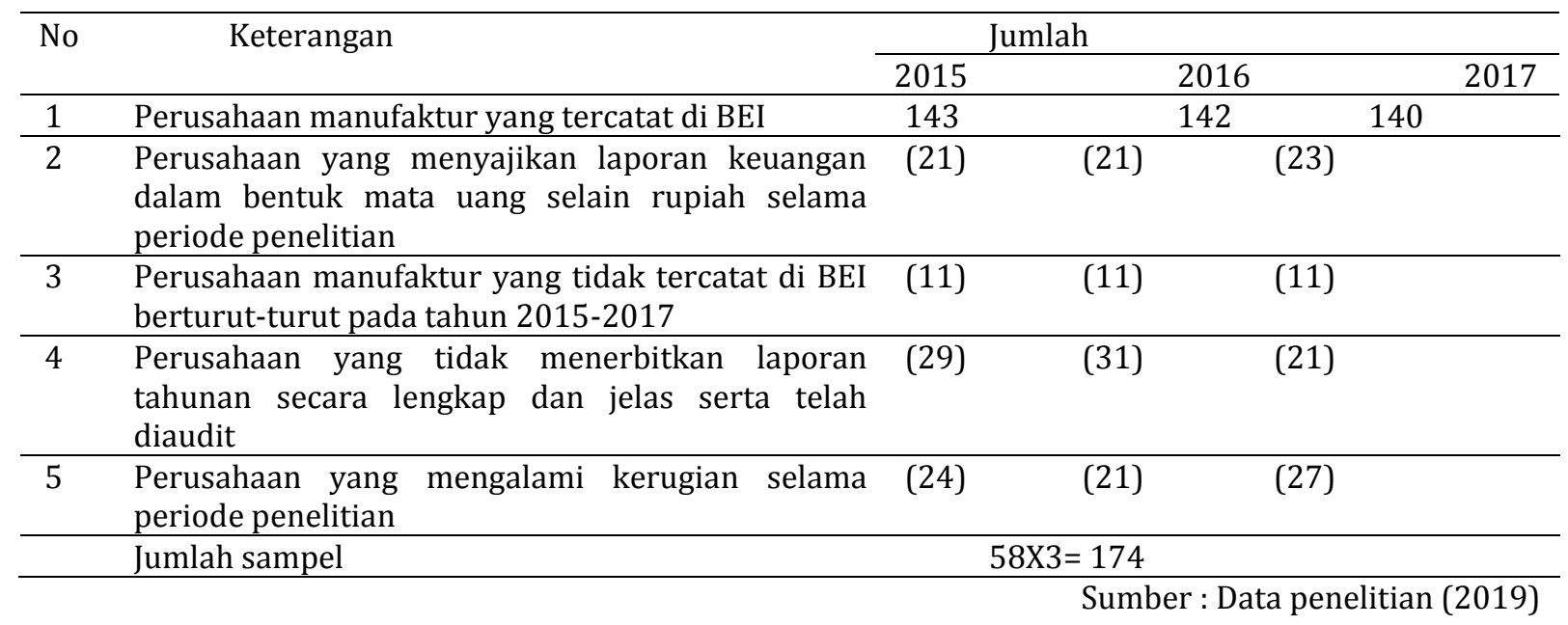

Pada Table 2 diatas, diketahui bahwa jumlah data yang digunakan dalam penelitian ini adalah 174 data yang diambil dari laporan tahunan pada perusahaan manufaktur yang terdaftar di Bursa Efek Indonesia (BEI) pada tahun 2015-2017.

Uji Asumsi Klasik

Uji Normalitas

Uji normalitas dilakukan untuk menguji apakah model regresi, variabel residual dalam penelitian ini berdistribusi data normal atau tidak. Penelitian ini menggunakan analisis grafik Normal P-P Plot of Regression Standardized Residual untuk melihat data tersebut normal atau tidak. Jika persebaran titik berada di sekitar sumbu diagonal dan mengikuti garis diagonal, makamodel regresi penelitian ini memenuhi asumsi normalitas (Juliandi, 2013). Berikut ini merupakan grafik Normal P-P Plot of Regression Standardized Residual dari model regresi berganda dalam penelitian ini: 


\section{Normal P.P Plot of Regression Standardized Residual}

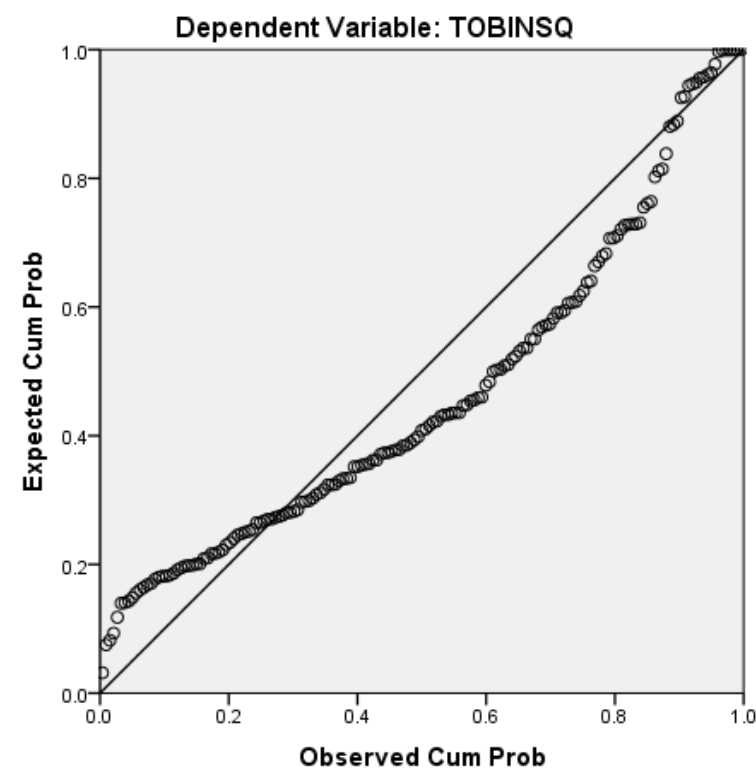

Gambar 1. Hasil Uji Normalitas

Pada grafik gambar 1 diatas menunjukkan bahwa titik-titik menyebar disekitar garis diagonal dan mengikuti arah garis diagonal, maka nilai residual tersebut normal, sehingga model regresi dalam penelitian ini berdistribusi normal dan memenuhi asumsi normalitas.

\section{Uji Heteroskedastisitas}

Uji heteroskedastisitas bertujuan untuk menguji apakah dalam model regresi terdapat ketidaksamaan varian residual suatu pengamatan ke pengamatan yang lain. Pengujian heteroskedastisitas di penelitian ini menggunakan analisis grafik scatterplot dari model regresi penelitian ini. Jika persebaran titik data dalam grafik scatterplot berada dibawah dan diatas angka nol pada sumbu Y dan tidak membentuk pola yang jelas maka tidak terjadi heteroskedastisitas (Santoso, 2011). Berikut ini merupakan grafik scatterplot dari model penelitian ini.

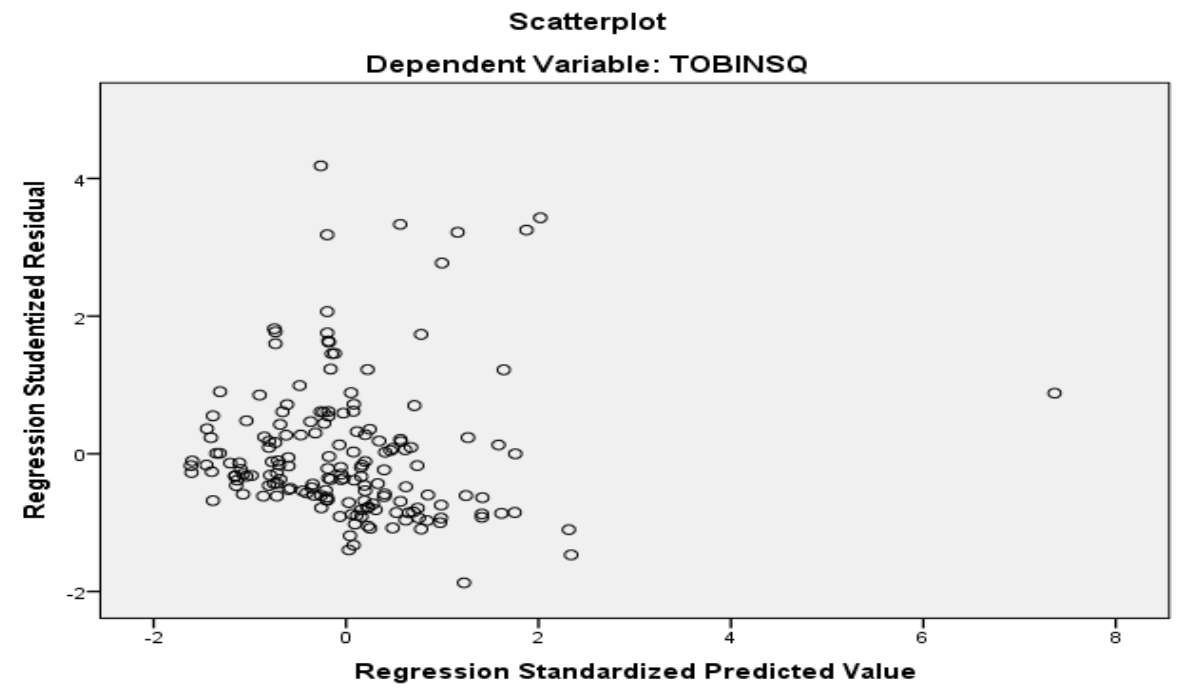

Gambar 2. Hasil Uji Heteroskedastisitas

Pada grafik scatterplot diatas menunjukkan bahwa persebaran titik-titik data berada diatas dan dibawah angka nol pada sumbu Y dan tidak membentuk pola dengan jelas, sehingga model regresi pada penelitian ini lolos uji heteroskedastisitas. 
Uji Multikolinearitas

Uji multikolinearitas bertujuan untuk menguji ada tidaknya multikolinearitas pada penelitian ini dengan melihat dari nilai tolerance dan variance inflation factor (VIF) dari tiap variabel. Jika nilai tolerance $\geq 0,10$ dan nilai VIF $\leq 10$ maka dapat disimpulkan bahwa model regresi bebas dari uji multikolinearitas.

Tabel 3. Coefficients ${ }^{\mathrm{a}}$

\begin{tabular}{lllc}
\hline \multirow{2}{*}{ Model } & & \multicolumn{2}{c}{ Collinearity Statistics } \\
\cline { 2 - 4 } 1 & & Tolerance & VIF \\
\cline { 2 - 4 } & (Constant) & .996 & 1.004 \\
\cline { 2 - 4 } & ETR & .998 & 1.002 \\
\cline { 2 - 4 } & KM & .996 & 1.004 \\
\hline
\end{tabular}

a. Dependent Variable: TOBINSQ

Berdasarkan hasil pengujian penelitian diatas diketahui bahwa nilai VIF ETR $(1,004), K M(1,002)$ dan variabel moderating TP $(1,004)$ dan nilai tolerance ETR $(0,996), K M(0,998)$ dan TP $(0,996)$. Karena nilai tolerance $\geq 0,10$ dan nilai VIF $\leq 10$ untuk semua variabel tersebut maka dapat disimpulkan bahwa penelitian ini tidak terjadi gangguan multikolinearitas atau dengan kata lain model regresi ini lolos dari uji multikolinearitas.

Uji Autokorelasi

Uji autokorelasi bertujuan untuk mengetahui apakah terdapat korelasi antar suatu periode dengan periode sebelumnya. Untuk menguji adanya autokorelasi dalam penelitian ini digunakan pengujian Durbin-Watson (DW). Jika nilai DW lebih besar dari nilai dU dan lebih kecil dari nilai 4-dU maka tidak terdapat autokorelasi, sehingga lolos dari uji autokorealsi.

Nilai DW dalam penelitian ini adalah 2,013, untuk $\mathrm{n}=174$ dan $\mathrm{k}=4$ pada level alpha 5\% diperoleh nilai $\mathrm{dL}=1,7052$ dan nilai $\mathrm{dU}=1,7992$, nilai 4 - $\mathrm{dU}=2,2008$. Oleh karena itu nilai $\mathrm{dU}=1,7992<\mathrm{DW}=$ $2,013<(4-\mathrm{dU})=2,2008$. Maka dapat disimpulkan bahwa penelitian tidak terjadi autokorelasi pada model regresi atau lolos dari uji autokorelasi.

Tabel 4. Hasil Uji Autokorelasi

\begin{tabular}{ccccccc}
\hline Persamaan & $\mathrm{dL}$ & $\mathrm{Du}$ & $4-\mathrm{Du}$ & 4-dL & DW & Kesimpulam \\
\hline 4 & 1,7052 & 1,7992 & 2,2008 & 2,2948 & 2,013 & Lolos \\
\hline
\end{tabular}

Hasil Pengujian

Pengujian hipotesis penelitian ini menggunakan analisis regresi sederhana untuk mengetahui pengaruh antara perencanaan pajak terhadap nilai perusahaan. Berikut ini adalah hasil analisis regresi linear berganda dalam penelitian ini.

Tabel 5. Hasil Pengujian Pengaruh Perencanaan Pajak terhadap Nilai Perusahaan Coefficients ${ }^{a}$

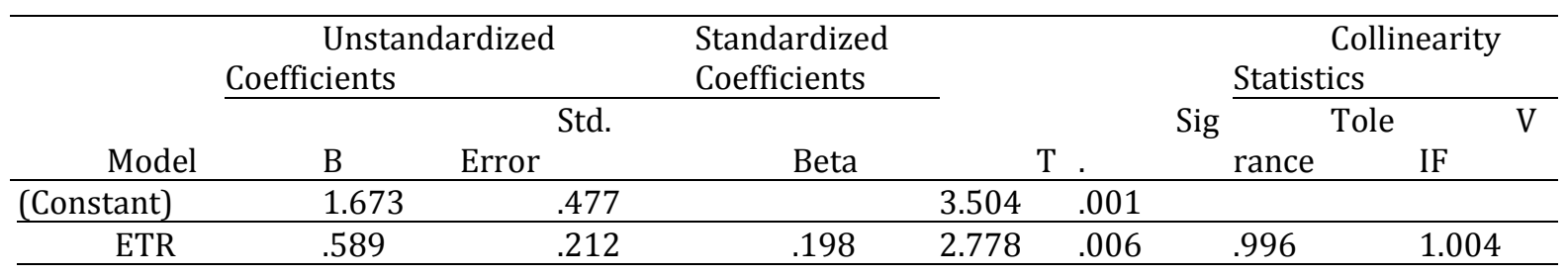

a. Dependent Variable: TOBINSQ

Sumber: Data penelitian (2019)

Hasil penelitian diatas menunjukkan nilai konstanta pada persamaan analisis regresi sederhana dalam penelitian ini yaitu 1,673 dengan nilai sig. 0,001. Nilai konstanta tersebut memiliki arti ketika perencanaan pajak konstan, maka nilai variabel nilai perusahaan adalah 1,673. Nilai $\beta 1$ yang diperoleh dalam persamaan regresi sederhana ini yaitu sebesar 0,589 dan nilai sig. sebesar 0,006 menunjukkan bahwa perencanaan pajak berpengaruh positif terhadap nilai perusahaan dengan tingkat signifikansi 5 persen. 
Tabel 6. Hasil Pengujian Pengaruh Kepemilikan Manajerial terhadap Nilai Perusahaan Coefficientsa

\begin{tabular}{|c|c|c|c|c|c|c|c|c|}
\hline \multirow[b]{3}{*}{ Model } & \multicolumn{2}{|c|}{$\begin{array}{l}\text { Unstandardized } \\
\text { Coefficients } \\
\end{array}$} & \multirow{3}{*}{$\begin{array}{c}\begin{array}{c}\text { Standardiz } \\
\text { ed Coefficients }\end{array} \\
\text { Beta } \\
\end{array}$} & \multirow[b]{3}{*}{$\mathrm{t}$} & \multirow[b]{3}{*}{ g. } & \multicolumn{3}{|c|}{$\begin{array}{l}\text { Collinearity } \\
\text { Statistics } \\
\end{array}$} \\
\hline & & & & & & $\mathrm{Si}$ & Tole & VI \\
\hline & $\mathrm{B}$ & Std. Error & & & & rance & & $\mathrm{F}$ \\
\hline (Constant) & 1.673 & .477 & & 3.504 & .001 & & & \\
\hline $\mathrm{KM}$ & -.071 & .029 & -.177 & -2.487 & .014 & .998 & & 1.002 \\
\hline
\end{tabular}

a. Dependent Variable: TOBINSQ

Sumber: Data penelitian (2019)

Hasil penelitian diatas menunjukkan nilai konstanta pada persamaan analisis regresi sederhana dalam penelitian ini yaitu 1,673 dengan nilai sig. 0,001. Nilai konstanta tersebut memiliki arti ketika kepemilikan Manajerial konstan, maka nilai variabel nilai perusahaan adalah 1,673. Nilai $\beta 2$ yang diperoleh dalam persamaan regresi sederhana ini yaitu sebesar $-0,71$ dan nilai sig. sebesar 0,014 menunjukkan bahwa kepemilikan manajerial berpengaruh negatif terhadap nilai perusahaan dengan tingkat signifikansi 5 persen.

Tabel 7. Hasil pengujian hipotesis 3a Model Summary

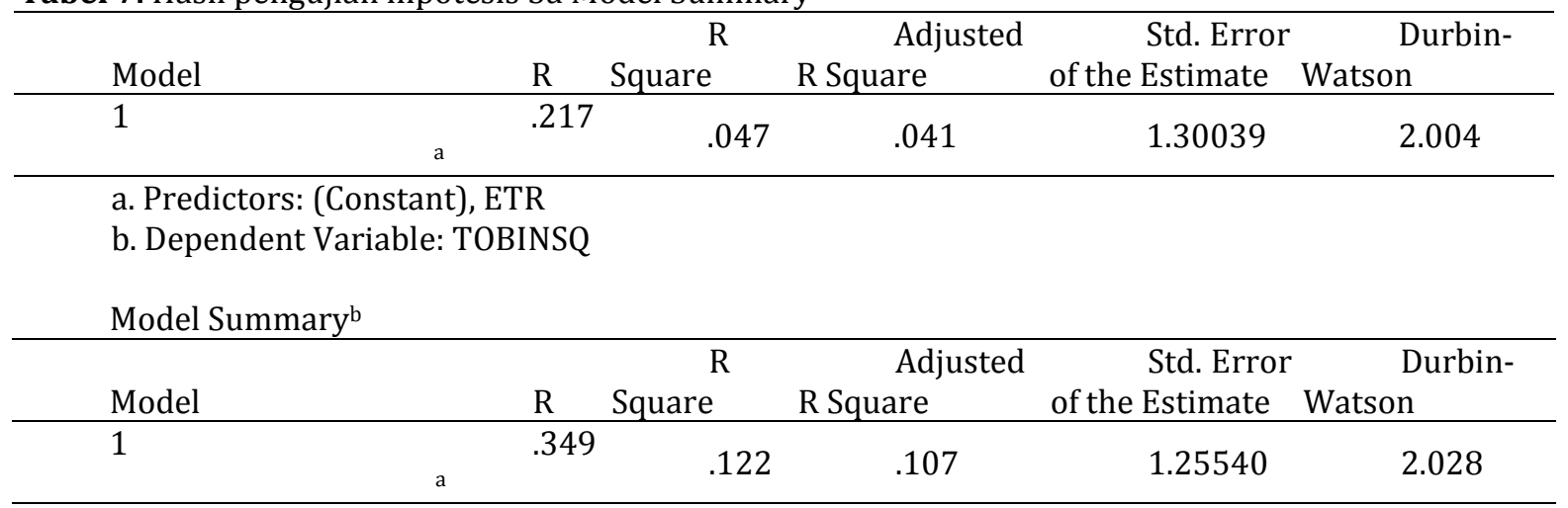
a. Predictors: (Constant), TP_ETR, TP, ETR
b. Dependent Variable: TOBINSQ

Sumber: Data penelitian (2019)

Hasil penelitian diatas menunjukkan nilai $\mathrm{R}^{2}$ pada regresi pertama sebesar 0,047 atau 4,7 persen sedangkan setelah ada persamaam regresi kedua nilai $\mathrm{R}^{2}$ naik menjadi 0,122 atau 12,2 persen. Dengan melihat hasil tersebut maka, transparansi perusahaan memoderasi pengaruh perencanaan pajak terhadap nilai perusahaan.

Tabel 8 Hasil pengujian hipotesis 3b Model Summary ${ }^{b}$

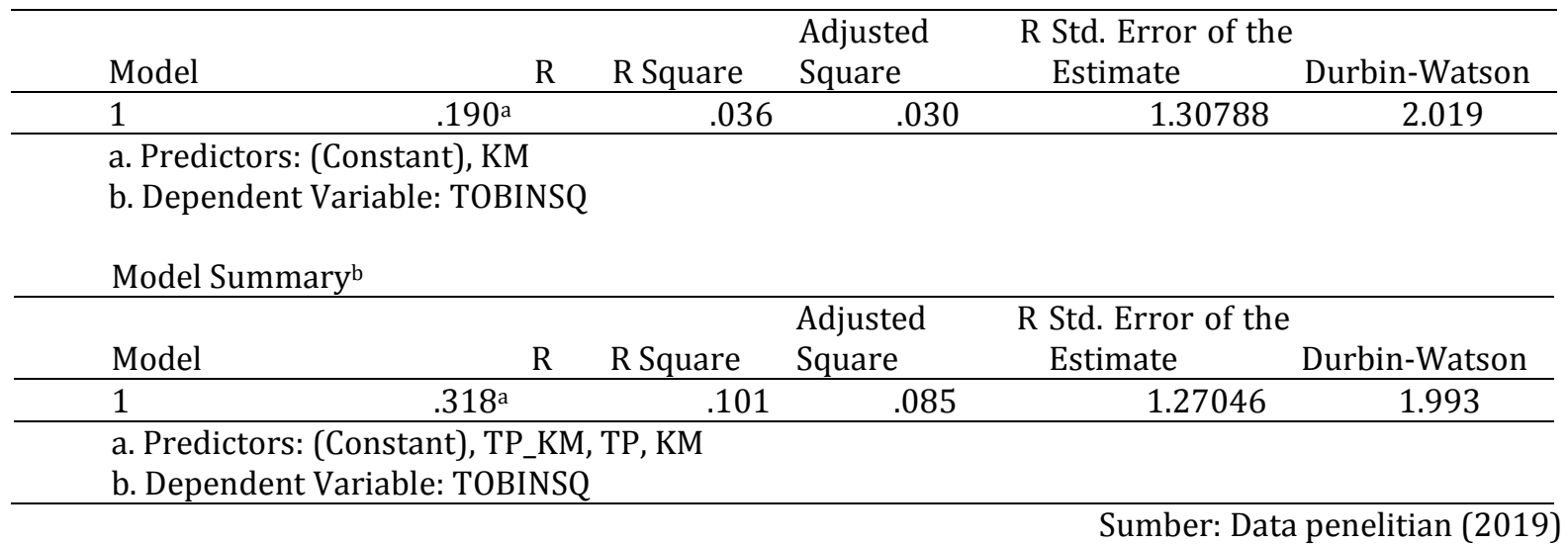


Hasil penelitian diatas menunjukkan nilai $\mathrm{R}^{2}$ pada regresi pertama sebesar 0,036 atau 3,6 persen sedangkan setelah ada persamaam regresi kedua nilai $\mathrm{R}^{2}$ naik menjadi 0,101 atau 10,1 persen. Dengan melihat hasil tersebut maka, transparansi perusahaan memoderasi pengaruh kepemilikan manajerial terhadap nilai perusahaan.

Berdasarkan pengujian hipotesis didapat bahwa perencanaan pajak berpengaruh positif terhadap nilai perusahaan, maka hipotesis pertama dalam penelitian ini ditolak. Hasil penelitian ini sejalan dengan penelitian Martani et.al. (2012) dan Nanik (2014) yang menyatakan bahwa perencanaan pajak memiliki pengaruh positif terhadap nilai perusahaan. Artinya semakin besar perencanaan pajak yang dilakukan maka dapat meningkatkan nilai perusahaan. Perencanaan pajak yang dilakukan oleh perusahaan juga berguna untuk meningkatkan kesejahteraan pemegang saham bukan untuk kepentingan pribadi. Nilai perusahaan tersebut akan tinggi jika perusahaan memperhatikan kemakmuran dan kepuasan pemegang sahamnya. Hal ini dilihat sebagai prospek oleh pasar sehingga harga saham naik.

Berdasarkan pengujian hipotesis didapat bahwa kepemilikan manajerial berpengaruh negatif terhadap nilai perusahaan, maka hipotesis kedua dalam penelitian ini ditolak. Hasil penelitian ini sejalan dengan penelitian Sukirni (2012) dan Sugiarto (2011) bahwa kepemilikan saham yang rendah oleh pihak manajemen mengakibatkan manajer lebih mengutamakan kesejahteraannya terlebih dahulu baru kemudian kesejaterahan perusahaan. Penurunan nilai perusahaan ini dikarenakan akibat tindakan oportunistik yang dilakukan oleh para pemegang saham manajerial. Kepemilikan manajerial menginginkan pendapatan yang tinggi dibandingkan dengan pertumbuhan investasi dalam perusahaanya, sehingga semakin besar kepemilikan manajerial dalam susunan pemegang saham akan menyebabkan rawan tindakan yang lebih mementingkan kepentingan manajer dari pada kepentingan pemegang saham, hal ini berdampak pada reaksi negatif pasar yang berdampak pada menurunnya nilai perusahaan serta nilai saham perusahaan.

Berdasarkan pengujian tersebut didapat bahwa dengan adanya transparansi perusahaan akan dapat memoderasi pengaruh perencanaan pajak terhadap nilai perusahaan dan transparansi perusahaan akan dapat memoderasi pengaruh kepemilikan manajerial terhadap nilai perusahaan. Hal ini dapat dilihat dari $\mathrm{R}^{2}$ pada hasil pengujian diatas. Hasil tersebut yang menunjukkan sebelum adanya variabel transparansi perusahaan bahwa nilai $\mathrm{R}^{2}$ untuk variabel perencanaan pajak sebesar 4,7 persen dan nilai $\mathrm{R}^{2}$ untuk variabel kepemilikan manajerial sebesar 3,6 pesen, tetapi setelah ditambahkan dengan variabel moderasi yaitu transparansi perusahaan nilai $\mathrm{R}^{2}$ untuk variabel perencanaan pajak naik sebesar 12,2 persen dan untuk variabel kepemilikan manajerial sebesar 10,1 persen. Maka hipotesis 3a dan hipotesis $3 \mathrm{~b}$ dalam penelitian ini diterima. Hal ini di karenakan banyak informasi yang diungkapkan oleh manajemen pada laporan keuangan atau tahunannya, maka pemilik perusahaan dan investor dapat lebih mengetahui kondisi peusahaan yang sebenarnya. Selain itu, akses informasi juga menjadi mudah dan menjadi salah satu indikator dari transparansi perusahaan dalam menyampaikan informasinya kepada pihak diluar perusahaan. Dengan adanya transparansi perusahaan ini maka kesempatan dari manajemen untuk memiliki niatan untuk menguntungkan pribadinya akan dapat dikurangi. Sehingga perencanaan pajak yang dilakukan oleh manajemen akan dapat memberikan manfaat yang baik bagi pemilik perusahaan serta bagi manajemen. Dari hal ini juga akan memberikan dampak positif kepada pihak luar ataupun calon investor, dan juga hal tersebut juga dapat membantu untuk meningkatkan nilai perusahaan.

\section{Simpulan dan saran}

Berdasarkan penelitian yang telah dilakukan, dapat disimpulkan yaitu, pertama, perencanaan pajak berpengaruh positif terhadap nilai perusahaan. Kedua, kepemilikan manajerial berpengaruh negatif terhadap nilai perusahaan. Ketiga, transparansi perusahaan memoderasi pengaruh perencanaan pajak terhadap nilai perusahaan. Keempat, transparansi perusahaan memoderasi pengaruh kepemilikan manajerial terhadap nilai perusahaan. Terdapat beberapa keterbatasan dalam penelitian ini yang bisa mempengaruhi hasil penelitian. (1) informasi laporan tahunan hanya diperoleh dari website BEI. (2) terdapat data laporan tahunan yang tidak lengkap karena tidak mempresentasikan keseluruhan data.

Berdasarkan penelitian yang telah dilakukan maka saran yang bisa penulis berikan yaitu: bagi perusahaan diharapkan untuk menjaga kekonsistenan pengungkapan informasi sukarelanya, agar informasi yang diberikan tetap aman dan tidak membingungkan bagi para pemakai informasi. Bagi peneliti selanjutnya diharapkan untuk menambah periode penelitian tidak hanya tiga periode dan memperluas obyek penelitian tidak hanya pada perusahaan manufaktur saja, serta item-item pengungkapan sukarela bisa lebih disesuaikan dengan yang lebih baru lagi dan menggunakan metode selain ETR untuk mendapatkan perspektif yang berbeda. 


\section{Daftar Rujukan}

Armstrong, C. S. (2015). Corporate Governance, Incevtives, and Tax Avoidance. Journal of Accounting and Economics, , 60 (1), 1-17.

Budiman, J. (2012). Pengaruh Karakter Eksekutif terhadap Penghindaran Pajak (Tax Avoidance). Jurnal Universitas Islam Sultan Agung.

Chasbiandani, T., \& Martani, D. (2012). Pengaruh Tax Avoidance Jangka Panjang. Jurnal dan Prosiding SNA - Simposium Nasional Akuntansi, Vol 15.

Diyah P, \& W.Erman. (2009). Pengaruh Struktur Kepemilikan Terhadap Nilai Perusahaan: Keputusan Keuangan sebagai Variabel Intervening. Jurnal konomi Bisnis dan Akuntansi Ventura, Vol. 12. No.1, h. 71-86.

Hairi, Muhammad Hidayat, \& Akbar, M. I. (2016). Pengaruh Perencanaan Pajak Dan Modal Intelektual Terhadap Nilai PerusahaaPada Perusahaan Jasa Keuangan Yang Terdaftar Di Bursa Efek Indonesia Periode 2009-2013. Jurnal Ilmiah Ekonomi Global Masakini , 7(2), pp: 23-29.

Haruman, T. (2008). Pengaruh Struktur Kepemilikan Terhadap Keputusan Keuangan Dan Nilai Perusahaan Survey pada Perusahaan Manufaktur di PT. Bursa Efek Indonesia. SNA XI : Ikatan Akuntan Indonesia .

Holland, Nor Shaipah Abdul Wahab, \& Kevin. (2012). Tax Planning, Corporate Governance and Equity Value. British Accounting Review , Vol 44,(2).

Hutami. (2011). Tax Planning (Tax Avoidance dan Tax Evasion) dilihat dari teori Etika. www.ortax.org .

Ilmiani, A. d. (2014). Pengaruh Tax Avoidance terhadap Nilai Perusahaan dengan Transparansi Perusahaan Sebagai Variabel Moderating. Jurnal Ekonomi dan Bisnis , 14(1), pp:30-39.

Industri.bisnis.com. (2017, May 30). Retrieved from https://www.industri.bisnis.com

Jensen dan Meckling dalam Winanto, W. (2013). Pengaruh Perencanaan Pajak dan Mekanisme Corporate Governance terhadap Nilai Perusahaan. Jurnal dan Prosiding SNA - Simposium Nasional Akuntansii XVI, Vol 16.

Juliandi. (2013). Metodologi Penelitian Kuantitatif. Bandung: Cita Pustaka Media Perintis .

Lestari, N. (2014). PENGARUH TAX PLANNING. Akuntabilitas: Vol. VII , 69-83.

Martani, T. C. (2012). Pengaruh Tax Avoidance Jangka Panjang Terhadap Nilai Perusahaan. Makalah Simposium Nasional Akuntansi XV Banjarmasin 2012.

Nike, Y., Yunilma, \& Zaitul. (2014). Pengaruh Perencanaan Pajak dan Corporate Governance Terhadap Nilai Perusahaan. e-jurnal Bung Hatta, Volume 4.

Ningsih, H. R. (2013). Pengaruh Kepemilikan Manajerial dan Rasio Pengembalian Aktiva Terhadap Nilai Perusahaan (Studi Kasus pada Industri Perbankan yang Terdaftar di Bursa Efek Indonesia). . Jurnal Universitas Komputer Indonesia.

Nurlela, \& Islahuddin. (2008). Pengaruh Corporate Social Responsibility terhadap Nilai Perusahaan dengan Prosentase Kepemilikan Manajemen sebagai Variabel Moderating. Simposium Nasional Akuntansi XI. Pontianak .

Nuryaman. (2009). Pengaruh Konsentrasi Kepemilikan, Ukuran Perusahaan, dan Mekanisme Corporate Governance terhadap Pengungkapan Sukarela. Jurnal Akuntansi dan Keuangan Indonesia , 6(1), pp:89-116. 
Partha, I. d. (2016). Pengaruh Penghindaran Pajak Jangka Panjang Pada Nilai Perusahaan dengan Transparansi Informasi Sebagai Variabel Pemoderasi. Jurnal Akuntansi Universitas Udayana. 14 (30). , $2336-2362$.

Pradyana, I. B. (2017). Pengaruh Perencanaan Pajak Terhadap Nilai Perusahaan Dengan Transparansi Perusahaan Sebagai Variabel Moderasi. EJurnal Akuntansi Universitas Udayana , 18(2), pp:13981425.

Santoso. (2011). Mastering SPSS. Jakarta: Kompas Gramedia .

Sofyaningsih, S., \& Hardiningsih, P. (2011). Struktur Kepemilikan, Kebijakan Dividen, Kebijakan Utang, dan Nilai Perusahaan. Dinamika Keuangan dan Perbankan. , Vol. 3, No.1, hal. 68-87.

Suandy, E. (2011). Perencanaan Pajak. Jakarta: Salemba Empat.

Sugiarto, M. (2011). Pengaruh Struktur Kepemilikan dan Kebijakan Dividen terhadap Nilai Perusahaan dengan Kebijakan Hutang sebagai Variabel Intervening. Jurnal Akuntansi Kontemporer, Vol.3, No.1 , hal.1-25.

Suhartati, T., Warsini, S., \& Sixpria, N. (2011). Pengaruh Pengungkapan Tanggung Jawab Sosial dan Praktek Tata Kelola Perusahaan terhadap Nilai Perusahaan. Jurnal Ekonomi dan Bisnis , Vol 10, N0. 2, : 95-105.

Torihoran, A. (2016). Pengaruh Penghindaran Pajak Dan Leverage Terhadap Nilai Perusahaan Dengan Transparasi Perusahaan Sebagai Variabel Moderasi. Jurnal Wira Ekonomi Mikroskil , 6(2), pp:149164.

Wilson, R. (2009). An Examination of Corporate Tax Shelter Participants. The Accounting Review , 84(3), pp:969- 999.

Winanto, U. W. (2013). Pengaruh Perencanaan Pajak dan Mekanisme Corporate Governance terhadap Nilai Perusahaan. Jurnal dan Prosiding SNA - Simposium Nasional Akuntansii XVI , Vol 16.

Yuono, C. A. (2016). Pengaruh Perencanaan Pajak dan Corporate Governance Terhadap Nilai Perusahaan. Jurnal Ilmu dan Riset Akuntansi , Vol 5. 